\title{
Effect of Municipal Solid Waste Compost, Rock Phosphate and Phosphate Solubilizing Bacteria on Nutrients Uptake and Yield in Wheat
}

\section{Muhammad Atif Jamil ${ }^{1}$, Tanveer Iqbal ${ }^{2}$, Fahad Karim Awan ${ }^{3}$, Anwaar Hussain', Weinbiao Duan ${ }^{1}$ and Muhammad Ali Raza ${ }^{4}$}

${ }^{1}$ Department of soil and water conservation and desertification control, School of Forestry Northeast Forestry University, Harbin-150040, Pr China

${ }^{2}$ Institute of soil science PMAS-AAUR, Rawalpindi, Pakistan

${ }^{3}$ Pakistan agriculture research center Islamabad, Pakistan.

${ }^{4}$ College of agronomy, Sichuan Agriculture University, Chengdu 611130, Pr China

*Corresponding author

\section{A B S T R A C T}

\begin{tabular}{|c|}
\hline Keywords \\
\hline $\begin{array}{l}\text { MSWC, rock } \\
\text { phosphate, nutrients } \\
\text { uptake and yield }\end{array}$ \\
\hline Article Info \\
\hline $\begin{array}{l}\text { Accepted: } \\
20 \text { May } 2018 \\
\text { Available Online: } \\
\text { 10 June } 2018\end{array}$ \\
\hline
\end{tabular}

Municipal solid waste compost (MSWC), rock phosphate (RP) and phosphate solubilizing bacteria (PSB) @ $20 \mathrm{ml} \mathrm{pot}^{-1}$ were applied as soil amendment to investigate its effect on soil, nutrients uptake and yield in wheat (Triticum aestivum, L.). Maximum up take of potassium (K) $\mathrm{mg} \mathrm{kg}^{-1}$, Phosphorous $(\mathrm{P}) \mathrm{mg} \mathrm{kg}^{-1}$ and Nitrogen $(\mathrm{N}) \mathrm{mg} \mathrm{kg}^{-1}$, Iron $(\mathrm{Fe}) \mathrm{mg}$ $\mathrm{kg}^{-1}$, Copper $(\mathrm{Cu}) \mathrm{mg} \mathrm{kg}^{-1}$, Manganese $(\mathrm{Mn}) \mathrm{mg} \mathrm{kg}^{-1}$ and Zinc $(\mathrm{Zn}) \mathrm{mg} \mathrm{kg}^{-1}$ was observed with the application of RP @1000 kg ha ${ }^{-1}+$ MSWC @ $20 \mathrm{t} \mathrm{ha}^{-1}$. Significant increase in plant height, fresh weight plant ${ }^{-1}$, grain weight plant $^{-1}$ and spike length was found by the same treatment, Significant difference was also observed with application of PSB on soil nutrients, nutrients uptake and yield in wheat. It was also observed soil parts hydrogen $(\mathrm{Ph})$ and electric conductivity $(\mathrm{Ec}) \mathrm{ds} \mathrm{m}^{-1}$ remained unaffected by all the treatments applied. Comparing all the treatments, it can be concluded that rock phosphate $1000 \mathrm{~kg} \mathrm{ha}^{-}$ ${ }^{1}+$ MSWC @ 120 ton ha ${ }^{-1}$ can affectively improve the soil nutrients (macro and micro) uptake with significant increase in yield attributes in wheat.1

\section{Introduction}

The application of municipal solid waste compost (MSWC), rock phosphate (RP) and phosphate solubilizing bacteria (PSB) as soil amendment is of economic and environmental interest to sustain natural resources like soil and water for increasing food production is a serious challenge to be addressed in $21^{\text {st }}$ century. Long term food security requires a balance between crop production and soil health/ fertility. However, imbalanced application of chemical fertilizers or excessive nutrient supply not only affect on nutrient use efficiency (Aulakh, 2010), but also deteriorates the soil structure, atmosphere and quality of underground water (Aulakh et al., 2009).

In developed countries municipal solid waste compost (MCWC) is considered as a new soil amendment to compensate other organic composts like farm yard manure and poultry manure (Cherif et al., 2009). Solid waste management. SWMC can be used as a low grade manure and soil conditioner. MCWC is generally low in nutrition therefore less acceptable to the farmers, hence enrichment of 
MSWC is necessary to improve nutrient status and quality of compost (Kavitha and Subramanian, 2007).

Phosphate solubilizing microorganisms (PSM) along with rock phosphate (RP) is a chaper source of phosphorous (P) fertilizer in crop production resulting in higher yield (Khan et al., 2004). The effect of phosphate solubilizing bacteria was found significant on plant height, grain yield, straw yield and at nutrients uptake in wheat (Hossain et al., 2004).

Considering the quality and nutritional significance of MSWC, the study was conducted to investigate best combination of MSWC, with phosphatic fertilizer, rock phosphate and phosphorous solubilizing bacteria on plants nutrient uptake and yield in wheat.

\section{Materials and Methods}

\section{Treatments and Experimental Design}

A pot experiment was conducted in two factorial completely randomized design with three replications to investigate the effects of rock phosphate application along with organic manures (municipal solid waste compost and rock phosphate) on soil and plants of wheat. Factor 1: mineral and organic phosphorous (P) source (rock phosphate) and Factor 2: Psolubilizing bacteria. Treatments were applied with and without phosphorous solubilizing bacteria (PSB) WPs-8 inoculated @ 20ml pot

${ }^{1}$. The detail of treatments is as under:-

Treatments detail

$\mathrm{T}_{1}=$ control

$\mathrm{T}_{2}=\mathrm{P}$ fertilizer $@ 90 \mathrm{~kg} \mathrm{ha}^{-1}$

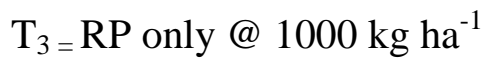

T $4=\mathrm{RP} @ 1000 \mathrm{kgha}^{-1}+\mathrm{MSWC} @ 10$ ton $\mathrm{ha}^{-1}$

T5=RP @ $1000 \mathrm{kgha}^{-1}+$ MSWC @ 20 ton ha $^{-1}$

Soil sample was taken before sowing and after harvesting wheat crop. Before sowing composite sample was taken from all pots and soil analysis was done showing in Table. 2....Variety of wheat was chakwal-50 and 20 seeds per pots were sown and after germination only 8 plants per pot were selected.

\section{Chemical Analysis}

Samples were dried in hot air oven at $65{ }^{\circ} \mathrm{C}$ for 24 hours. Dried samples were grinded and stored in plastic bottles. Plant and compost samples were digested with $\mathrm{H} 2 \mathrm{SO} 4$-salicylic acid mixture in block digester and heated to $400{ }^{\circ} \mathrm{C}$. After digestion, distillation with $10 \mathrm{~N}$ $\mathrm{NaOH}$ and titration against $0.01 \mathrm{~N} \mathrm{H}_{2} \mathrm{SO}_{4}$ will be carried out total nitrogen will be calculated with following formula (Buresh et al., 1982)

Wet digestion was done according to (Issac and Johnson 1975). Digested filtrate was used to measure total phosphorus clorimetrically. Potassium was analyzed by using digested filtrate directly by flame photometer. Micronutrients (Fe, $\mathrm{Cu}, \mathrm{Mn}, \mathrm{Zn}$ ) were analyzed using digested filtrate directly by flame photometer.

Macronutrients (N, P, K) and Micronutrients (Fe, $\mathrm{Cu}, \mathrm{Zn}, \mathrm{Mn}$ ) in soil and rock phosphate were determined through AB-DTPA Method (Soltanpour and Workman, 1979) Electrical conductivity was determined using soil to distilled water ratio of 1:1 (Rhoades, 1982).

Soil $\mathrm{pH}$ was determined using soil to distilled water ratio of $1: 1$ by calibrated $\mathrm{pH}$ meter (Mclean, 1982). 


\section{Statistical Analysis}

The data collected was analyzed by using appropriate statistical analysis tools (Steel et al., 1997).

\section{Results and Discussion}

There were no significant differences $(p<0.05)$ between the soil $\mathrm{pH}$ values of all the soil treatments with and without phosphorous solubilizing bacteria (Table. 3) similar results were obtained by Bouzaiane et al., (2007). Data in (Table. 4) revealed that none of treatment has influence on fresh weight of plant, spike length plant ${ }^{-1}$ and number of tillers plant $^{-1}$. Grain weight plant ${ }^{-1}$ was maximum $(3.46 \mathrm{~g})$ and $(3.5 \mathrm{~g})$ with and without PSB by $\mathrm{T}_{5}$. These results are in accordance with (Cherif et al., 2009) who reported a noticeable increase in grain yield by MSWC and other organic fertilizers compared to control. Plant height showed significant difference with in treatments and where PSB was applied. Plant height was maximum $(68.8 \mathrm{~cm})$ by $\mathrm{T}_{5}$ followed by $(66.8 \mathrm{~cm})$ which was produced by the treatment $\mathrm{T}_{4}$ with PSB. While the same treatments $\mathrm{T}_{5}$ and $\mathrm{T}_{4}$ showed maximum plant height $(65.6 \mathrm{~cm})$ and $(63.38 \mathrm{~cm})$ without PSB. The findings are in accordance with results of Afzal, et al., (2005) and Ali et al., (2003) who observed MSWC has positive effects on plant height. However Kumari et al., (2002) reported a significant increase in sorghum plant height by inoculation of different bacterial strains.

\section{Macro and micronutrient content in soil}

Data in (Table.3) reveals that $\mathrm{P}$ content of soil after harvesting increased significantly among the treatments and a significant difference was noted where PSB applied and where PSB was not applied. These findings are in unity with results observed by Noor et al., (2005) and Kavitha et al., (2007) who reported that there was increase in $p$ content in soil by applying phosphobacteria, rock phosphate and organic manure. Results in also shows that $\mathrm{K}$ and $\mathrm{N}$ content of soil after harvest also increased significantly among treatments but application of PSB made no significant difference in soil K. Maximum K (182 $\left.\mathrm{mg} \mathrm{kg}^{-1}\right), \mathrm{P}\left(7.6 \mathrm{mg} \mathrm{kg}^{-1}\right)$ and $\mathrm{N}\left(14.7 \mathrm{mg} \mathrm{kg}^{-1}\right)$ was found in the samples collected from plots where RP @ $1000 \mathrm{~kg} \mathrm{ha}^{-1}$ + MSWC @ 20 ton ha ${ }^{-1}$ was applied with PSB.

These findings are in agreements with results of Noor et al., (2005). While data regarding nitrate-nitrogen of soil presented in table. 3 reflects that there was significant difference present among the treatments but application of PSB had no significant effect on nitrate nitrogen content in soil. These findings relates with sharif et al., (2011) who reported PSB had no significant effects on soil nitrogen content.

\section{Macro and Micronutrients uptake in wheat}

Data presented in (Table.5) demonstrates that $\mathrm{P}$ uptake in wheat was significant among treatments applied but PSB did not showed any significant effect on the uptake of $P$ except where rock phosphate is applied with PSB. These findings are similar to Imran et al., (2011) who studied the effect of DAP, RP, and RP enriched compost on maize crop and concluded that DAP showed the highest $\mathrm{P}$ uptake followed by RP enriched compost and RP. Potassium uptake by wheat plants revealed that there was significant increase in $\mathrm{K}$ uptake by the application of different treatments and higest concntration was occurred where compost was applied $\mathrm{T}_{5}(1.75$ $\%)$ and $\mathrm{T}_{4}(1.59 \%)$ with PSB. The findings are in confirmation with Han et al., (2006) who conclude that there was boost in uptake of $\mathrm{K}$ in pepper by addition of RP with phosphorus solublising bacteria as compared to the treatments without phosphorus solublising bacteria. 
Table.1 Analysis of rock phosphate and MSWC compost used

\begin{tabular}{|c|c|c|c|c|c|c|c|}
\hline $\begin{array}{c}\text { Treatments } \\
\text { Detail }\end{array}$ & $\mathbf{N}$ & $\mathbf{P}$ & $\mathbf{K}$ & $\mathrm{Fe}$ & $\mathbf{C u}$ & $\mathbf{Z n}$ & Mn \\
\hline RP & $21 \mathrm{ppm}$ & $190 \mathrm{ppm}$ & $43 \mathrm{ppm}$ & $28 \mathrm{ppm}$ & $6.8 \mathrm{ppm}$ & $4 \mathrm{ppm}$ & $\mathbf{8 . 4} \mathrm{ppm}$ \\
\hline MSWC & $\mathbf{1 . 2 \%}$ &. $\mathbf{4 3} \%$ & $\mathbf{1 . 1 \%}$ & $\mathbf{2 2 8 1} \mathrm{ppm}$ & $\mathbf{2 2} \mathrm{ppm}$ & $\mathbf{3 1 0} \mathrm{ppm}$ & $\mathbf{3 1 2} \mathrm{ppm}$ \\
\hline
\end{tabular}

Table.2 Physicochemical properties of experimental soil

\begin{tabular}{|l|l|}
\hline Soil properties & Concentration \\
\hline $\mathbf{p H}$ & 7.75 \\
\hline Ec $(\mathbf{d S} / \mathbf{m})$ & 0.42 \\
\hline Texture & sandy loam \\
\hline $\mathrm{NO}_{3}-\mathrm{N}(\mathbf{m g} / \mathbf{~ k g})$ & 6.53 \\
\hline Available P $(\mathbf{m g} / \mathbf{k g})$ & 5.01 \\
\hline Potassium $(\mathbf{m g} / \mathbf{k g})$ & 125 \\
$\mathbf{F e}(\mathbf{m g} / \mathbf{k g})$ & 8.2 \\
Copper$(\mathbf{m g} / \mathbf{k g})$ & 0.50 \\
Zinc $(\mathbf{m g} / \mathbf{k g})$ & 0.65 \\
$\mathbf{M n}(\mathbf{m g} / \mathbf{k g})$ & 12.5 \\
\hline
\end{tabular}

Table.3 Macronutrients, EC, $\mathrm{pH}$ in soil

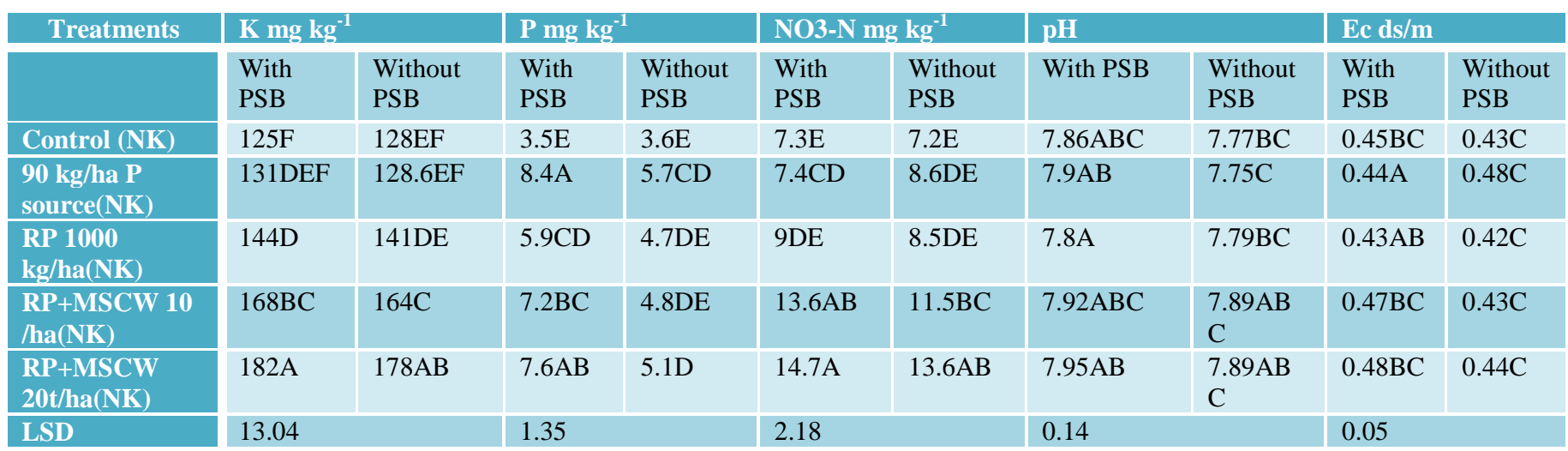

LSD $=$ Least significant difference

Table.4 Physical parameters

\begin{tabular}{|c|c|c|c|c|c|c|c|c|c|c|}
\hline \multirow[t]{2}{*}{ Treatments } & \multicolumn{2}{|c|}{ Heightplant $^{1}$} & \multicolumn{2}{|c|}{ Fresh wt/ plant } & \multicolumn{2}{|c|}{ Spike length } & \multicolumn{2}{|c|}{$\begin{array}{l}\text { Number of Tillers/ } \\
\text { plant }\end{array}$} & \multicolumn{2}{|c|}{ Grain weight/ plan } \\
\hline & With PSB & $\begin{array}{l}\text { Without } \\
\text { PSB }\end{array}$ & With PSB & $\begin{array}{l}\text { Withou } \\
\text { t PSB }\end{array}$ & With PSB & $\begin{array}{l}\text { Without } \\
\text { PSB }\end{array}$ & With PSB & $\begin{array}{l}\text { Without } \\
\text { PSB }\end{array}$ & $\begin{array}{l}\text { With } \\
\text { PSB }\end{array}$ & $\begin{array}{l}\text { Without } \\
\text { PSB }\end{array}$ \\
\hline Control & $53.00 \mathrm{E}$ & $54.50 \mathrm{D}$ & $3.2 \mathrm{C}$ & $3.7 \mathrm{D}$ & 7.16 D & $7.0 \mathrm{E}$ & $2.63 \mathrm{C}$ & $3 \mathrm{~A}$ & $3.0 \mathrm{E}$ & $2.85 \mathrm{D}$ \\
\hline $\begin{array}{l}90 \mathrm{~kg} / \mathrm{ha} \mathrm{P} \\
\text { source }\end{array}$ & $65.00 \mathrm{C}$ & $61.63 \mathrm{~B}$ & $5.8 \mathrm{~A}$ & $4.5 \mathrm{~A}$ & $8.01 \mathrm{C}$ & $8.10 \mathrm{C}$ & $3.03 \mathrm{~B}$ & $3.6 \mathrm{~A}$ & $4.87 \mathrm{~A}$ & $3.33 \mathrm{~A}$ \\
\hline $\begin{array}{l}\text { RP 1000 } \\
\text { kg/ha }\end{array}$ & $55.60 \mathrm{D}$ & $60.10 \mathrm{C}$ & $3.3 \mathrm{C}$ & $3.2 \mathrm{E}$ & $8.13 \mathrm{C}$ & $7.63 \mathrm{D}$ & $3.03 \mathrm{~B}$ & $3.3 \mathrm{~A}$ & $3.1 \mathrm{D}$ & $2.83 \mathrm{D}$ \\
\hline $\begin{array}{l}\text { RP+MSCW } \\
10 \text { t/ha }\end{array}$ & $66.63 \mathrm{~B}$ & $52.36 \mathrm{E}$ & $4.7 \mathrm{~B}$ & $4.1 \mathrm{C}$ & $8.60 \mathrm{~B}$ & $8.26 \mathrm{~B}$ & $3.10 \mathrm{~B}$ & $3.3 \mathrm{~A}$ & $3.26 \mathrm{C}$ & $3.06 \mathrm{C}$ \\
\hline $\begin{array}{l}\text { RP+MSCW } \\
\text { 20t/ha } \\
\end{array}$ & $68.40 \mathrm{~A}$ & $65.70 \mathrm{~A}$ & $5.3 \mathrm{~A}$ & $4.3 \mathrm{~A}$ & $9.0 \mathrm{~A}$ & $8.56 \mathrm{~A}$ & $3.33 \mathrm{~A}$ & $3.6 \mathrm{~A}$ & $3.46 \mathrm{~A}$ & $3.20 \mathrm{~B}$ \\
\hline LSD & 3.86 & & 0.59 & & 1.5 & & 1.42 & & 0.32 & \\
\hline
\end{tabular}

$\mathrm{LSD}=$ Least significant difference 
Table.5 Macronutrient uptake by wheat

\begin{tabular}{|l|l|l|l|l|l|l|}
\hline \multicolumn{1}{|c|}{ Treatments } & \multicolumn{3}{c|}{ K\% } & \multicolumn{3}{c|}{ P\% } \\
\hline & With PSB & Without PSB & With PSB & Without PSB & With PSB & Without PSB \\
\hline Control & $0.66 \mathrm{D}$ & $0.62 \mathrm{D}$ & $0.41 \mathrm{~A}$ & $0.47 \mathrm{~B}$ & $1.8 \mathrm{~B}$ & $1.7 \mathrm{C}$ \\
\hline $\mathbf{9 0} \mathrm{kg} / \mathrm{ha}$ P source & $1.27 \mathrm{C}$ & $0.86 \mathrm{C}$ & $0.73 \mathrm{~A}$ & $0.61 \mathrm{~A}$ & $1.7 \mathrm{~B}$ & $1.87 \mathrm{~B}$ \\
\hline RP 1000 kg/ha & $0.28 \mathrm{E}$ & $0.54 \mathrm{E}$ & $0.83 \mathrm{~A}$ & $0.47 \mathrm{~B}$ & $1.8 \mathrm{~B}$ & $1.5 \mathrm{C}$ \\
\hline RP+MSCW 10 t/ha & $1.46 \mathrm{~B}$ & $1.3 \mathrm{~B}$ & $0.50 \mathrm{~A}$ & $0.37 \mathrm{D}$ & $2.4 \mathrm{~A}$ & $1.86 \mathrm{~B}$ \\
\hline RP+MSCW 20t/ha & $1.71 \mathrm{~A}$ & $1.50 \mathrm{~A}$ & $0.63 \mathrm{~A}$ & $0.40 \mathrm{C}$ & $2.5 \mathrm{~A}$ & \multicolumn{2}{c|}{$2.32 \mathrm{~A}$} \\
\hline LSD & & 0.17 & & 0.28 & & 0.31 \\
\hline
\end{tabular}

$\mathrm{LSD}=$ Least significant difference

Table.6 Micronutrient uptake by wheat

\begin{tabular}{|c|c|c|c|c|c|c|c|c|}
\hline Treatments & \multicolumn{2}{|c|}{ Fe mg kg-1 } & \multicolumn{2}{|c|}{$\mathrm{Cu} \mathrm{mg} \mathrm{kg}{ }^{-1}$} & \multicolumn{2}{|c|}{ Mn mg kg-1 } & \multicolumn{2}{|l|}{ Zn mg kg ${ }^{-1}$} \\
\hline & $\begin{array}{l}\text { With } \\
\text { PSB }\end{array}$ & $\begin{array}{l}\text { Without } \\
\text { PSB }\end{array}$ & $\begin{array}{l}\text { With } \\
\text { PSB }\end{array}$ & $\begin{array}{l}\text { Without } \\
\text { PSB }\end{array}$ & $\begin{array}{l}\text { With } \\
\text { PSB }\end{array}$ & $\begin{array}{l}\text { Without } \\
\text { PSB }\end{array}$ & With PSB & $\begin{array}{l}\text { Without } \\
\text { PSB }\end{array}$ \\
\hline Control & $78.3 \mathrm{E}$ & $76.9 \mathrm{E}$ & $16.8 \mathrm{~B}$ & $14.6 \mathrm{E}$ & $26.7 \mathrm{E}$ & $23.4 \mathrm{E}$ & $17.4 \mathrm{E}$ & $15.6 \mathrm{E}$ \\
\hline $90 \mathrm{~kg} / \mathrm{ha}$ P source & $94.47 \mathrm{C}$ & 79.7 C & $21.6 \mathrm{~B}$ & $19.1 \mathrm{D}$ & $42.4 \mathrm{C}$ & $32.1 \mathrm{D}$ & $21.6 \mathrm{D}$ & $19.4 \mathrm{D}$ \\
\hline RP 1000 kg/ha & 83.6 D & $74.4 \mathrm{E}$ & $28.7 \mathrm{AB}$ & $25.3 \mathrm{C}$ & $34.4 \mathrm{D}$ & $32.9 \mathrm{C}$ & $27.3 \mathrm{C}$ & $23.6 \mathrm{C}$ \\
\hline $\begin{array}{l}\text { RP+MSCW } 10 \\
\text { t/ha }\end{array}$ & $98.9 \mathrm{~B}$ & $83.9 \mathrm{~B}$ & $39.1 \mathrm{~A}$ & $33.1 \mathrm{~B}$ & $48.4 \mathrm{~B}$ & $42.7 \mathrm{~B}$ & $42.8 \mathrm{~B}$ & $39.0 \mathrm{~B}$ \\
\hline $\begin{array}{l}\text { RP+MSCW } \\
\text { 20t/ha }\end{array}$ & $105.2 \mathrm{~A}$ & $93.4 \mathrm{~A}$ & $40.2 \mathrm{~A}$ & $43.6 \mathrm{~A}$ & $56.4 \mathrm{~A}$ & $53.6 \mathrm{~A}$ & $49.9 \mathrm{~A}$ & $43.4 \mathrm{~A}$ \\
\hline LSD & \multicolumn{2}{|l|}{7.86} & \multicolumn{2}{|l|}{4.44} & \multicolumn{2}{|l|}{7.43} & \multicolumn{2}{|l|}{6.28} \\
\hline
\end{tabular}

$\mathrm{LSD}=$ Least significant difference

Total nitrogen of the plant samples ranged from $1.7 \%$ to $2.5 \%$ in Table.5. The results showed non-significant differences among different treatments applied. There was no significant effect of PSB was showen on uptake of nitrogen. These observations are at par with those of Minja et al., (2008) who found that green manure along RP was more effective than other treatments.

Data in (Table.6) regarding micronutrients (Fe. $\mathrm{Cu}, \mathrm{Mn}, \mathrm{Zn}$ ) in soil shows significant increase in micro nutrients uptake among treatments. These findings are in conformity with Roghanian et al., (2012) who observed increase in availability and uptake of iron $(\mathrm{Fe})$, manganese $(\mathrm{Mn})$, Zinc $(\mathrm{Zn})$ and Nickle (Ni) with the application of municipal waste compost leachate. Application of PSB did not have any effect on the concentration of micronutrients $(\mathrm{Fe}, \mathrm{Cu}, \mathrm{Mn})$ but significant difference was noted in case of zinc ( $\mathrm{Zn})$ with in soil. These results supported kumari et al., (2002) who reported that compost treated plot enhanced micronutrient up take.

These studies provide an insight in understatnding, how municipal solid waste compost (MSWC) and rock phosphate (RP) in addition of phosphorous solublizing bacteria (PSB) result in agronomically pheasible, envoronmentally sound and economically viable sustainable production system by maintaining and enhancing soil ferlitilty status, reducing nutrient losses and improving nutrients uptake in plants resulting in improved crop production. From the above study it is suggested that MSWC and RP with PSB can be effective soil treatment to improve soil fertility status and increased economical yield in wheat. 


\section{References}

Afzal, A., M. A. Saeed, A. Asad and M. Farooq. 2005. Effect of phosphate solubilizing microorganisms on phosphorous uptake, yield and yield traits of wheat (Triticum aestivum L.) in Rainfed area. Int. J. Agri. Biol., 2: $207-$ 209.

Ali, H. I., M. R. Ismail, M. M. Manan and H. M. Saud. 2003. Rice straw compost used as a soil less media for organic tomato transplant production. Asian J. Microbial. Biotechnol. Environ. Sci. 5:31-36.

Aulakh, M. S. 2010. Integrated nutrient management for sustainable crop production, improving crop quality and soil health, and minimizing environmental pollution. World Congress of Soil Sci. 1-6 August, Brisbane, Australia.

Aulakh, M. S., M.P. S. Khurana and D. Singh. 2009. Water pollution related to agricultural, industrial and urban activities, and its effects on food chain; Case studies from Punjab. J. New Seeds. 10: 112-137.

Bouzaiane, O., H. Cherif, F. Ayari, N. Jedidi and A. Hassen. 2007. Municipal solid waste compost does effects on soil microbial biomass determined by chloroform fumigation-extraction and DNA methods. Annals of Microbioloy. 57: 681-686.

Buresh, R. J., P. C. Austin and E. T. Craswell. 1982. Analytical methods in $\mathrm{N}-15$ research. Fert. Res., 3: 37-62.

Cherif, H., F. Ayari, H. Ouzari, M. Marzorati, L. Brusetti, N. Jedidi, A. Haseen and D. Daffonchio. 2009. Effects of municipal waste compost, farmyard manure and chemical fertilizers on wheat growth, soil composition and soil bacteria characteristics under Tunisian arid climate. European J. Soil Biol. 45: 138145.

Han, H., S. Supanjan and K. D. Lee. 2006. Effect of co-inoculation with phosphate and potassium solublizing bacteria on mineral uptake and growth of pepper and cocummber. Plant Soil Env., 3: 130-136.

Hossain, M. B., M. A. Sattar and M. Z. Islam. 2004. Characterization and effect of phosphate solubilizing bacteria in wheat. J. Agric. Res. 42: 3-4.

Imran, M. 2011. Effect of recycled and value added organic waste on solubilization of rockphosphate in soil and its influence on maize growth. Int. J. Agri. and Biol., 36: 138-156.

Issac, R. A and W. C. Johnson. 1975. Collaboration study of wet and dry ashing techniques for elemental analysis of plant tissue by atomic absorption spectrophotometer. J. Assoc. Annal. Chem., 58: 436-440.

Kavitha, R. and P. Subramanian. 2007. Effect of enriched municipal waste compost application on growth, plant nutrient uptake and yield of rice. J. Agronomy. 6: 586-592.

Khan, M. S., A. Zahid and M. Aamil. 2004. Bioassociative effect of rhizospheric microorganisms on growth, yield and nutrient uptake of greengram. L. Plant Nutri., 27: 599610.

Kumari, M. S and K. Ushakumari. 2002. Effect of vermicompost enriched with rock phosphate on yield and uptake of nutrients in cowpea. J. Tropical Agri. 40: 27-30.

Mclean, K. S. 2005. Soil and fertilizer Phosphorous. In: Soil Science. A. Rashid and K. S. Memon. Edited by E. Bashir and R. Bantel. Roohani Art Press Isb.

Minja, R. R., A. P. Maerere, C. L. Rweyemamu and G. G. Kimbi. 2008. Effects of amending compost and green 
manure with phosphate rock on quality of amaranth. Afr. J. Hort. Sci., 1: 70-71.

Noor, A. 2005. The role of rock phosphate and farm yard manure compibed phosphate solubilizing bacteria in increasing nutrient uptake and soybean yield. J. Land and Environ. 7: 41-47.

Rhoades, J. D. 1982. Soluble salts (Electrical conductivity), R. H. Miller and O. R. keeneys (eds), Methods of soil analysis part 2. ASA. No. 9. Madison, Wiconsin, USA, pp.172-173.

Roghanian, S., H. M. Hosseini, G. Savaghebi, L. Halajian, M. Jamei and H. Ethseami. 2012. Effects of composted municipal waste and its leachate on some soil chemical properties and corm plant response. Intern. J. Agri,: Res and Rev. 2: 801-814.

Sharif, M. 2011. Response of dung compost with rock phosphate on yield and phosphorous and nitrogen uptake of maize crop. Afri. J. Biotech. 10: 1259512601.

Soltanpour, P. N. and S. Workman. 1979. Modification of the $\mathrm{NAHCO}_{3}$ DTPA soil test to omit carbon black. Commun. Soil Sci. Plant Anal., 10:1411-1420.

Steel, R. G. D., J. H. Torrie and M. A. Boston. 1997. Principles and procedures of statistics: A biometrical approach, ed. McGraw Hill Book company Inc. New York, pp. 633.

\section{How to cite this article:}

Tanveer Iqbal, Muhammad Atif Jamil, Fahad Karim Awan, Anwaar Hussain, Weinbiao Duan and Muhammad Ali Raza. 2018. Effect of Municipal Solid Waste Compost, Rock Phosphate and Phosphate Solubilizing Bacteria on Nutrients Uptake and Yield in Wheat. Int.J.Curr.Microbiol.App.Sci. 7(06): 2858-2864. doi: https://doi.org/10.20546/ijcmas.2018.706.336 